\title{
Nitrat: karakteristik antinutrisi, dampak negatif, potensi aditif, dan efektivitas agen defaunasi
}

\section{Nitrates: antinutritional characteristics, negative impacts, additive potential, and effectiveness of defaunate agents}

\author{
Mila Riskiatul Rohma', Irfan Zubairi', Aldian Dwi Aryono1, Lanang \\ Nasrullah ${ }^{1}$, dan Desy Cahya Widianingrum²* \\ ${ }^{1}$ Mahasiswa Program Studi Peternakan, Fakultas Pertanian, Universitas Jember, Jl. \\ Kalimantan No. 37, Jember, 68121 \\ ${ }^{2}$ Program Studi Peternakan, Fakultas Pertanian, Universitas Jember, Jl. Kalimantan \\ No. 37, Jember, 68121 \\ *Email Koresponden: dsycahya312@gmail.com
}

\begin{abstract}
Abstrak. Kajian pustaka ini memberikan informasi karakteristik, dampak negatif, dan potensi aditif, dan efek positif dari penggunaan antinutrisi nitrat. Antinutrisi merupakan komponen senyawa metabolit sekunder yang terkandung di dalam tanaman dan dapat membahayakan ternak. Dampak negatif dari nitrat diantaranya keracunan pada ternak akibat reduksi nitrat dalam darah membentuk methamoglobin (MetHb) dan berpotensi menyebabkan keguguran pada ternak bunting akibat hypoxia. Meskipun demikian, nitrat dalam konsentrasi rendah dapat digunakan sebagai aditif pakan dan berdampak positif bagi produktifitas ternak. Pemanfaatan nitrat dalam bahan pakan hijauan bermanfaat sebagai agen defaunasi pada rumen ternak ruminansia. Penurunan populasi protozoa dalam rumen dapat meningkatkan kecernaan serat kasar sehingga bersifat menguntungkan karena terjadinya efisiensi produksi dan meningkatnya pertumbuhan ternak. Efek positif bagi lingkungan dengan adanya defaunasi adalah menurunkan emisi gas metan sebagai hasil dari proses metabolisme ternak ruminansia. Kesimpulan dari tulisan ini adalah senyawa antinutrisi pada pakan disamping memiliki dampak negatif, juga besar kemungkinan memiliki potensi yang dapat dimanfaatkan baik bagi ternak maupun lingkungan.
\end{abstract}

Kata kunci: keracunan nitrat, agen defaunasi, global warming, aditif pakan potensial

Abstract. This study aimed to provide information on the characteristics, negative effects, and potential of additives, and the positive effects of using nitrate antinutrients. Antinutrients are components of secondary metabolites contained in plants and can harm livestock. The negative effects of nitrate include poisoning in livestock due to the reduction of nitrate in the blood to form methamoglobin (MetHb) and has the potential to cause miscarriage in pregnant cattle due to hypoxia. However, nitrate in low concentrations can be used as a feed additive and has a positive impact on livestock productivity. Utilization of nitrate in forage feed ingredients is useful as a defaunating agent in the rumen of ruminants. The decrease in the population of protozoa in the rumen can increase the digestibility of crude fiber so that it is beneficial because of production efficiency and increasing livestock growth. The positive effect on the environment by the presence of defaunation is to reduce methane gas emissions as a result of the metabolic processes of ruminants. The conclusion of this paper is that antinutrient compounds in feed, besides having a negative impact, are also likely to have potential that can be utilized for both livestock and the environment.

Keywords: nitrate poisoning, global warming defaunating agent, feed additive 
Rohma et al.

ANIMPRO: Conference of Applied Animal Science Proceeding Series

\section{PENDAHULUAN}

Efisiensi produksi merupakan kemampuan memanfaatkan pakan secara optimal untuk pertumbuhan, perkembangan, dan reproduksi. Keberhasilan usaha peternakan dapat tercermin dari tercapainya efisiensi produksi sehingga peternak mendapatkan keuntungan yang maksimal. Kandungan antinutrisi pada bahan pakan menjadi salah satu faktor yang mempengaruhi nilai nutrisi ransum pakan. Keberadaan antinutrisi dalam bahan pakan dapat menurunkan kualitas nutrisi, efisiensi konversi pakan dan produktivitas ternak (Yanuarto, Alfarisa, \& Soedarmanto, 2019). Meskipun, antinutrisi dikenal dapat menyebabkan dampak negatif apabila dikonsumsi oleh ternak, namun penggunaan senyawa antinutrisi dalam konsentrasi rendah dan dosis yang tepat dapat berdampak positif bagi produktifitas ternak.

Senyawa nitrat merupakan salah satu komponen antinutrisi dalam bentuk nitrogen yang terdapat dalam pakan ternak khususnya hijauan. Pada kondisi normal, keberadaan nitrat dalam pakan seringkali diabaikan dan tidak menjadi masalah untuk ternak ruminansia. Nitrat akan berbahaya jika terakumulasi dalam hijauan pakan ternak (HPT) dengan jumlah yang besar. Hal ini dapat menyebabkan keracunan pada ternak ruminansia (Mamvura et al, 2014). Sapi merupakan jenis ternak ruminansia yang lebih rentan terhadap efek toksisitas nitrat dibandingkan ternak domba dan kuda.

Di samping dampak negatif yang ditimbulkan dari efek toksisitas, nitrat pada dosis tertentu dapat memberi efek positif bagi ternak. Penggunaan dalam konsentrasi rendah dapat digunakan sebagai agen defaunasi untuk menekan pertumbuhan protozoa. Efek defaunasi sangat baik bagi lingkungan karena dapat meminimalisir produksi gas metan enterik yang dihasilkan ternak ruminansia. Efek positif lain yaitu penambahan nitrat dalam bahan pakan ruminansia dapat digunakan sebagai pengganti urea sumber Nitrogen Non-Protein. Nitrat mampu mengubah komposisi nitrogen urin dengan cara meningkatkan ammonia serta emisi nitrous oksida dari manure (Jayanegara, Anuraga, \& Ridla, 2019).

Protozoa merupakan predator bagi sebagian bakteri sehingga keberadaan protozoa dalam rumen oleh beberapa peneliti dianggap merugikan. Bakteri rumen berperan penting dalam mendegradasi serat pakan yang nantinya akan diuraikan sebagai energi, namun pada prosesnya kerja bakteri rumen terhambat karena keberadaan protozoa. Proses defaunasi bertujuan untuk merubah komposisi mikroba rumen. Jumlah bakteri yang tinggi akan memberikan kinerja pencernaan serat pakan yang tinggi sehingga diharapkan dapat tercapai efisiensi pakan. Salah satu metode defaunasi yang efektif adalah melalui manipulasi pakan dengan cara memanfaatkan nitrat sebagai feed aditif. Penulisan artikel ilmiah ini bertujuan untuk menganalisa lebih lanjut terkait karakteristik nitrat sebagai komponen antinutrisi, dampak negatif dan efek positif terhadap peningkatan efisiensi produksi melalui penggunaan nitrat sebagai suplemen pakan.

\section{MATERI DAN METODE}

Tulisan ini merupakan hasil kajian pustaka yang dikumpulkan dan disusun untuk memberikan informasi bagi pembaca mengenai dampak dan potensi antinutrisi nitrat. Kajian pustaka bersumber dari berbagai jurnal hasil penelitiaan, buku dan prospiding seminar. Sumber kajian pustaka merupakan hasil kajian terbaru karena mengambil refrensi dengan tahun terbit yaitu 2010-2021.

\section{Karakteristik Nitrat}

Nitrat merupakan bentuk nitrogen utama diperairan alami. Nitrat berasal dari ammonium yang masuk ke dalam badan sungai terutama melalui limbah domestik, konsentrasinya di dalam sungai akan semakin berkurang bila semakin jauh dari titik pembuangan yang disebabkan adanya aktifitas mikroorganisme di dalam air contohnya bakteri nitrosomonas (Mustofa, 2015). Sebenarnya nitrat ini kurang beracun dibandingkan dengan nitrit. Kandungan nitrat dalam hijauan yang dikonsumsi oleh hewan dalam konsentrasi tinggi, maka nitrat dalam rumen akan direduksi menjadi nitrit oleh bakteri rumen dan dapat mematikan hewan. Nitrit di dalam rumen selanjutnya diubah menjadi amonia yang digunakan oleh mikroba untuk membentuk asam amino dan mikroba protein baru. Pada dasarnya nitrat kurang beracun dibandingkan dengan nitrit. 
Rohma et al.

ANIMPRO: Conference of Applied Animal Science Proceeding Series

Kandungan nitrat bersifat toksik apabila hewan ternak mengkonsumsinya dengan konsentrasi tinggi dalam hijauan. Hal tersebut dikarenakan mikroba rumen yang tidak dapat mengkonversi nitrit menjadi amonia sehingga nitrit terakumulasi di dalam rumen.

Penentuan kadar nitrat bisa dilakukan dengan metode spektrofotometer menggunakan metode brusin dengan alat spektrofotometer pada panjang gelombang $410 \mathrm{~mm}$ (Putri, Purwiyanto, Agustriani 2019). Nitrat jarang ditemukan dalam jumlah besar pada tanaman kecuali pada saat kondisi gangguan alam. Kandungan nitrat paling tinggi dalam hijauan apabila mendapat perlakuan seperti pemakaian pupuk yang terlalu tinggi, kondisi lingkungan yang terlalu kering, kerusakan jaringan tanaman seperti defoliasi sebagai akibat dari aplikasi herbisida, tanaman yang mendapat intensitas cahaya terlalu rendah sehingga mengurangi aktifitas fotosintesis, dan keberadaan spesies tanaman yang tidak di inginkan seperti gulma tahunan. Pada tanaman leguminosa seperti semanggi putih, nitrogen diubah menjadi amonia selama fiksasi $\mathrm{N}$ biologis. Pada tanaman nonleguminosa seperti ryegrass, pada umumnya nitrogen diserap hampir secara eksklusif dalam bentuk $\mathrm{NO}_{3}$ - dan $\mathrm{NH}_{4}$ (Jayanegara et al., 2019).

\section{Dampak Negatif Nitrat Bagi Ternak}

Kandungan nitrat yang tinggi dapat merugikan produksi ternak dikarenakan penyerapan sumber energi menjadi berkurang yang pada utamanya berasal dari hasil fermentasi karbohidrat di dalam rumen. Dampak negatif yang umum terjadi dari konsumsi nitrat yang berlebihan adalah keracunan. Berdasarkan Jönck, Gava, \& Traverso (2013), keracunan secara spontan terjadi pada ternak sapi yang mengkonsumsi hijauan di padang rumput gandum dan ryegras dengan konsentrasi nitrat mulai dari $0.30-3.36 \%$ dalam bahan kering. Sebenarnya nitrat tidak terlalu toksik selama masih dalam ambang batas toleran, namun akan toksik jika dikonsumsi dalam jumlah banyak dan konsentrasi tinggi. Leng et al. (2015) menyatakan bahwa ada empat faktor utama yang menyebabkan terjadinya keracuan nitrat: (1) kadar nitrat dalam pakan, (2) tingkat konsumsi nitrat, (3) pengurangan nitrat dan nitrit yang tidak sempurna menjadi amonia dalam rumen, (4) laju aliran rumen yang lambat (retensi nitart atau nitrit yang lebih lama di dalam rumen).

Tabel 1. Tingkat Toksisitas Nitrat

\begin{tabular}{|c|c|c|c|}
\hline No. & Dosis Nitrat (ppm) & Kategori & Keterangan \\
\hline 1. & $0-2.500$ & Aman & Rata-rata aman di segala kondisi \\
\hline 2. & $2.500-5.000$ & Secara umum aman & $\begin{array}{l}\text { Aman apabila ternak diberi pakan dengan } \\
\text { ransum yang seimbang. Pada ternak bunting, } \\
\text { batas aman konsumsi nitrat adalah } 50 \% \text { dari } \\
\text { bahan kering dalam ransum. }\end{array}$ \\
\hline 3. & $5,000-15.000$ & Bahaya & $\begin{array}{l}\text { Batas aman adalah } 25 \% \text { dari bahan kering } \\
\text { ransum untuk pakan dengan komposisi ransum } \\
\text { yang seimbang. Ternak yang mengkonsumsi } \\
\text { nitrat dengan dosis pada kategori ini akan } \\
\text { mengalami penurunan produksi dan gangguan } \\
\text { reproduksi. }\end{array}$ \\
\hline 4. & $15.000-33.000$ & Toksin atau beracun & $\begin{array}{l}\text { Ternak tidak boleh diberi makan dengan bebas } \\
\text { memilih. Pakan hanya boleh diberikan kurang } \\
\text { dari } 15 \% \text { bahan kering dari total ransum. }\end{array}$ \\
\hline
\end{tabular}

Sumber: Glunk et al. (2015).

Akumulasi jumlah nitrit yang tinggi dapat masuk ke sistem pembuluh darah dan mengabsorbsi sel darah merah. Methemoglobin (MetHb) dibentuk dari rekasi nitrit dan hemoglobin yang berperan sebagai transport oksigen. Methemoglobin (MetHb) tidak dapat mengedarkan oksigen kedalam tubuh. Kejadian tersebut beresiko menyebabkan kematian karena ternak dapat 
Rohma et al.

ANIMPRO: Conference of Applied Animal Science Proceeding Series

mengalami kekurangan oksigen (Norberg \& Don, 2014). Keracunan nitrat pada ternak dibagi menjadi dua yaitu keracunan kronik sedang dan akut. Ternak yang mengalami keracunan kronik nitrat sedang akan menunjukan ciri sebagai berikut yaitu mata berair, penurunan nafsu makan, penurunan produksi susu, penurunan bobot badan, dan aborsi. Keracunan akut nitrat akan menunjukan gejala yang lebih parah seperti peningkatan denyut nadi, sesak napas, Tremor otot, lemas, sianosis hingga kematian (Glunk, March, \& Dave, 2015). Keracunan nitrat dikategorikan berdasarkan tingkat level nitrat didalam tubuh. Keracunan nitrat secara kronis juga dapat menyebabkan keguguran penurunan berat badan dan produksi susu, kekurangan vitamin $\mathrm{A}$, dan hipotiroidisme (Pfister, 2019), selengkapnya disajikan pada Tabel 1.

\section{Efek Positif Penggunaan Nitrat dalam Aditif Pakan}

Percobaan pada 8 sapi laktasi dengan penambahan nitrat sebanyak $2 \%$ pada pakan terbukti dapat meningkatkan asetat yang semula 51,5 menjadi $65,7 \%$, penurunan propionat dari jumlah awal $33,6 \%$ menjadi $20,9 \%$, dan tidak ada pengaruh pada butirat. Penambahan nitrat dengan kadar $2 \%$ juga tidak ada pengaruh pada tingkat toksiksitas, dan tidak ada perubahan yang signifikan pada komposisi susu. Aditif nitrat juga dilaporkan efektif sebagai penyerapan elektron dalam proses fermentasi rumen, terbukti dengan penurunan jumlah asam propionat dan butirat serta meningkatkan asetat (Hulshof, Berndt, \& Gerrits, 2012).

Dampak positif lain dari penambahan nitrat pada pakan yaitu dapat mereduksi emisi gas metan yang berasal dari kotoran hewan. Gas metan merupakan salah satu jenis gas rumah kaca (GRK) penyebab pemanasan global dan penipisan ozon (Cassandro, Mele, \& Stefanon, 2013). Berdasarkan IPPC (2014), tingkat bahaya gas metan dari sektor peternakan diperhitungkaan 28 kali lebih besar dibandingkan karbondioksida. Suplementasi nitrat pada pakan merupakan startegi untuk mitigasi emisi gas metan dari ternak ruminansia. Zhou, Yu, \& Meng (2012), melaporkan bahwa penggunaan nitrat dengaan dosis kurang dari $12 \mu \mathrm{mol} \mathrm{ml}^{-1}$ menunjukan hasil penurunan produksi gas metan secara efektif hingga 70 . Penambahan nitrat pada pakan domba menunjukan hasil yang signifikan dapat mengurangi populasi bakteri metanogen dan protozoa sehingga berdampak secara positif menekan produksi gas metan dirumen (Asanuma, Yokohama, \& Hino, 2014). Kandungan nitrat dan produksi metan dalam tubuh ternak pada beberapa studi disajikan pada Tabel 2 .

Tabel 2. Kandungan Nitrat dan Metan yang dihasilkan dalam Tubuh Ternak

\begin{tabular}{|c|c|c|c|c|}
\hline No. & Jenis Ternak & $\begin{array}{l}\text { Kandungan Nitrat } \\
\text { ( } \mathrm{g} / \mathrm{kg} \mathrm{BB})\end{array}$ & Produksi metan & Sumber \\
\hline 1 & Sapi potong & 0,51 & Tidak ada data & Hulshof, et al. (2012) \\
\hline 2 & Sapi potong & 0,62 & Tidak ada data & $\begin{array}{l}\text { Leng, Preston, \& } \\
\text { Inthapanya (2012) }\end{array}$ \\
\hline 3 & Domba & 0,94 & $25,7 \mathrm{~g} / \mathrm{kg} /$ hari & Li, Davis, \& Nolan (2012) \\
\hline 4 & Sapi Perah & 0,7 & $19,4 \mathrm{~g} / \mathrm{kg} / \mathrm{hari}(16 \%)$ & van Zijderveld (2011) \\
\hline 5 & Domba & 12,6 & $18,7 \mathrm{~g} / \mathrm{kg} / \mathrm{hari}$ & $\begin{array}{l}\text { El-Zaiat, Araujo, \& Soltan, } \\
(2014)\end{array}$ \\
\hline 6 & Studi in situ & $\begin{array}{c}0,2 \\
0,5 \\
1,1 \\
2\end{array}$ & $\begin{array}{l}80 \% \\
75 \% \\
80 \% \\
70 \%\end{array}$ & Wang, Zhou, \& Jia (2020) \\
\hline
\end{tabular}

\section{Peningkatan Efisiensi Produksi Melalui Defaunasi}

Di Indonesia, tingkat produktifitas ruminansia utamanya sapi terbilang cukup rendah dan belum sepenuhnya secara optimal berorientasi pada bisnis. Produktifitas yang rendah ini dapat ditinjau dari pemenuhan kebutuhan daging sapi dalam negeri yang masih didominasi oleh usaha peternakan rakyat dalam skala kecil. Rendahnya produktivitas tersebut disebabkan oleh beberapa faktor antara lain kandungan nutrien di dalam ransum, tingkat kecernaan yang rendah dan manajemen pemeliharaan yang belum optimal (Hapsari, Novia, \& Dian, 2018). Selain itu, 
Rohma et al.

ANIMPRO: Conference of Applied Animal Science Proceeding Series

faktor ekonomi dan tingkat Sumber Daya Peternak (SDM) menjadi alasan yang melatarbelaakangi peternak rakyat tidak dapat memberikan pakan yang cukup sesuai dengan kebutuhan nutrisi ternak.

Tingkat kecernaan pakan pada ternak ruminansia dipengaruhi adanya aktivitas populasi mikroba dalam rumen. Ransum pakan ternak ruminasia umumnya terdiri dari campuran hjauan dan konsentrat dimana bahan pakan ini sangat berguna sebagai prekusor pembentukan susu dan daging. Sementara itu, hijauan yang pada umumnya digunakan khususnya didaerah tropis cenderung mengandung lignoselulosa dan selulosa yang tinggi sehingga optimalisasi kerja bakteri rumen mendegradasi serat harus dilakukan (Lamid, Puspaningsih, \& Mangkoedihardjo, 2013). Proses pencernaan pada ternak ruminansia lebih banyak ditentukan oleh pencernaan fermentatif didalam rumen. Kapasitas rumen paling tinggi yakni kurang lebih $70 \%$ dari kapasitas saluran pencernaan secara keseluruhan, juga ekosistem rumen dan aktivitas mikroba. Dalam hal ini, pencernaan pakan secara fermentatif baik bahan kering atau bahan organik yang tergradasi semakin tinggi sejalan dengan lamanya proses fermentasi berlangsung. Kondisi fisiologi ini memberi makna bahwa pada waktu yang beersamaan aktivitas mikroba rumen mendegradasi pakan semakin meningkat, sehingga proses fermentasi diharapkan juga semakin tinggi (Haryanto, 2013)

Populasi mikroba rumen terdiri dari bakteri, protozoa dan fungi. Populasi bakteri di dalam rumen lebih tinggi dibandingkan populai protozoa dan fungi. Populasi bakteri rumen mencapai $10^{9} \mathrm{sel} / \mathrm{ml}$, sedangkan populasi protozoa mencapai $10^{6} \mathrm{sel} / \mathrm{ml}$ (Hapsari et al, 2018). Total protozoa didalam rumen pada setiap ternak bervariasi tergantung dari jenis pakan, umur dan jenis hewan yang menjadi inang (Dayyani, Karkudi, \& Zakerian, 2013). Keberadaan populasi protozoa bersifat merugikan sebab protozoa memangsa bakteri rumen untuk mendapatkan nutrisi. Bakteri rumen merupakan mikroba penting yang memiliki peran menguntungkan dalam membantu merombak pakan menjadi energi melalui proses enterik atau fermentasi pakan dirumen. Menurut Yanuartono et al. (2019), akibat yang ditimbulkan dari protozoa bersilia yang memangsa bakteri rumen diantaranya yaitu peningkatan daur ulang mikroba $\mathrm{N}$ dalam rumen dan penurunan suplai asam amino ke usus sebesar $20-28 \%$.

Menurut Holmes, Giloteaux, \& Orellana (2014), aktifitas metabolisme protozoa di rumen berakitan erat dengan pembentukan gas metan. Bakteri dan protozoa merupakan mikroflora yang berperan penting dalam mendukung kemampuan ternak ruminansia untuk mencerna pakan tinggi kandungan serat kasar. Peran protozoa dalam fermentasi rumen yaitu dengan cara mencerna pati sehingga $\mathrm{pH}$ rumen dapat bertahan dalam keadaan seimbang. Kemampuan protozoa dalam sintesis protein sangat rendah sehingga untuk memenuhi kebutuhan proteinnya protozoa memangsa bakteri yang termasuk mikroflora dirumen (Hapsari et al., 2018). Keberadaan protozoa dalam jumlah tinggi bersifat merugikan karena mengganggu keseimbangan rumen karena berkurangnya bakteri rumen sehingga berdampak pada terhambatnya proses pencernaan serat kasar. Upaya menekan pertumbuhan ppopulasi protozoa adalah melalui metode defanuasi. Metode defaunasi ditujukan agar tercipta kondisi lingkungan yang kondusif bagi pertumbuhan bakteri sehingga memaksimalkan kemampuan bakteri rumen dalam mencerna pakan seehingga akan dihasilkan produk fermentasi seperti VFA (Herliatika \& Widyawati, 2017).

Menurut Mosoni, Martin, \& Forano (2011), Keberadaan protozoa dalam rumen lebih banyak merugikan dibandingkan keuntungannya sebab peningkatan jumlah populasi protozoa didalam rumen mengakibakan penurunan fungsi kecernaan serat. Apabila populasi protozoa yang ada di dalam rumen ditekan jumlahnya, maka akan terjadi perubahan komposisi mikroba rumen yang mengarah pada dominasi bakteri rumen yang mendegradasi serat sehingga kecernaan serat dan pemanfaatan pakan akan meningkat dan selanjutnya pertumbuhan ternak dapat ditingkatkan. Peningkatan produktifitas dan kecernaan pakan pada ternak ruminansia dapat dilakukan melalui upaya defaunasi.

Defaunasi merupakan salah satu teknik manipulasi rumen sebagai upaha meningkatkan produktifitas ternak melalui efisiensi kecernaan sekaligus upaya mitigasi untuk menghambat produksi gas metan. Produksi gas metan enterik ternak ruminansia merupakan indikasi terjadinya pemborosan energi sebab proses kecernaan pakan yang kurang optimal atau inefisiensi (Herliatika \& Widiawati, 2021). Upaya defaunasi menjadi starategi untuk meningkatkan efisiensi 
Rohma et al.

ANIMPRO: Conference of Applied Animal Science Proceeding Series

produksi. Studi riset mengenai defaunasi telah banyak dikembangkan mulai dari metode defaunasi dengan penambahan bahan kimia ke dalam pakan, pencucian rumen, pengosongan rumen (Gebeyehu \& Mekasha, 2013), perubahan pakan (Aban \& Bestil, 2016) dan membesarkan hewan dalam isolasi. Metode penambahan feed aditif merupakan salah satu metode defaunasi yang efektif untuk menurunkan produksi gas metan. Nitrat merupakan senyawa antinutrisi atau metabolik sekunder tanaman yang dapat dimanfaatkan sebagai bahan aditif untuk defaunasi.

Penambahan nitrat dengan dosis yang tepat sebagai agen defaunasi terbukti secara efektif dapat menekan pertumbuhan populasi protozoa sebagai inang dari bakteri metanogen penghasil gas metan (Jayanegara et al., 2011). Berdasarkan hasil penelitian van Zijderveld, Gerrits, \& Dijkstra (2011) Penambahan nitrat sebanyak 2,1\% sebagai suplemen untuk pakan ternak sapi perah menunjukan hasil bahwa tidak terdapat pengaruh negatif terhadap produksi susu dan komposis susu. Oleh karena itu, pemanfaatan nitrat sebagai suplemen dengan dosis yang tepat sangat potensial sebab terbukti aman untuk ternak dan efektif menekan pembentukkan gas metan.

Emisi gas metan dalam ternak menjadi salah satu indikator inefisiensi metabolisme energi dalam tubuh ternak ruminansia. Senyawa metan dari ternak disebutkan sebagai salah satu penyumbang penyebab pemanasan global (Jayanegara et al., 2019). Hristov, Oh, \& Firkins (2013), menyatakan bahwa pada umumnya ternak ruminansia kehilangan sekitar lebih dari $5 \%$ energi makanan melalui produksi gas metan sebagai hasil samping dari proses fermentasi pakan didalam rumen.Oleh karena itu, pemanfaatan nitrat dalam pakan dapat menjadi suatu upaya menekan produksi gas metan didalam rumen perlu ditekan untuk terciptanya efisiensi kencernaan dan meningkatnya produktifitas ternak serta pengurangan emisi gas metan penyebab pencemaran lingkungan dari sektor peternakan.

\section{Strategi Penggunaan Aditif Nitrat dalam Pakan}

Terdapat beberapa strategi untuk penggunaan nitrat dalam pakan ternak sebagai upaya menurunkan toksisitas nitrat yaitu manajemen aklimasi dengan pemberian nitrat secara bertahap dan enkasulapsi nitrat. Pemberian nitrat secara bertahap merupakan strategi aklimasi yang bertujuan untuk proses adaptasi rumen untuk meningkatkan aktivitas atau populasi mikroba rumen yang mampu mengurangi nitrat menjadi amonia. Aklimasisasi dengan pemberian nitrat secara bertahap kepada ternak ruminansia kurang efektif karena keracunan nitrat masih dapat terjadi tergantung dari konsentrasi nitrat dalam bahan pakan dan tingkat konsumsi pakan (Lee, , Araujo, \& Koenig, 2015).

Enkasulapsi nitrat merupakan upaya pegembangan suplemen sebagai sumber nitrogen nonprotein (NPN), alternatif untuk meningkatkan kualitas pakan hijauan sekaligus untuk mengurangi produksi gas metan enternik pada ternak ruminasia (Mamvura et al., 2014). Penggunaan urea sebagai suplemen pakan hijauan memiliki kelemahan yaitu akan merugikan peternak apabila dosis penggunaannya tidak tepat sebab dapat bersifat toksin atau racun bagi ternak. oleh karena itu, suplementasi nitrat menjadi alternatif dari penggunaa urea pada pakan sebagai suplemen. Hal tersebut sesuai dengan pendapat beberapa ahli yang mengkonfirmasi bahwa penambahan nitrat pada pakan terbukti efisien dalam mengurangi emisi metan enterik tanpa menimbulkan gejala klinis dari tanda-tanda keracunan (Li et al. 2012; van Zijderveld, Gerrits, \& Dijkstra, 2010; van Zijderveld et al., 2011).

\section{KESIMPULAN}

Senyawa antinutrisi pada tanaman pakan menjadi faktor pembatas bagi konsumsi ternak. Keberadaanya sangat perlu diperhatikan sebab dalam konsentrasi diatas ambang batas toleransi ternak dapat menyebabkan efek biologis seperti keracunan atau toksisitas. Nitrat sebagai salah satu contoh antinutrisi pada pakan, disamping memiliki dampak negatif juga memiliki potensi yang dapat dimanfaatkan bagi ternak untuk meningkatkan produktifitas ternak ruminansia. Penambahan nitrat sebanyak kurang lebih $2 \%$ sebagai suplemen untuk pakan ternak sapi perah dilaporkan dapat meningkatkan kecernaan dan hasil produksi serta tidak berpengaruh negatif 
Rohma et al.

ANIMPRO: Conference of Applied Animal Science Proceeding Series

terhadap produksi dan komposis susu. Selain itu, Penambahan nitrat secara signifikan dapat menekan produksi gas metan sehingga efisien untuk produksii dan aman bagi lingkungan.

\section{DAFTAR PUSTAKA}

[IPCC] Intergovernmental Panel on Climate Change. (2014). 2013 Supplements to the 2006 IPCC Guidelines for National Greenhouse Gas Inventories: Wetlands. T Hiraishi, T Krug, K Tanabe, N Srivastava, J Baasansuren, M Fukuda, TG Troxler, editors. Switzerland: Intergovernmental Panel on Climate Change.

Aban, M., \& Bestil, L. (2016). Potential of some legume forages for rumen defaunatio

Asanuma, N., Yokoyama, S., \& Hino, T. (2014). Effects of nitrate addition to a diet on fermentation and microbial populations in the rumen of goats, with special reference toSelenomonas ruminantiumhaving the ability to reduce nitrate and nitrite. Animal Science Journal, 86(4), 378-384. doi:10.1111/asj.12307

Cassandro, M., Mele, M., \& Stefanon, B. (2013). Genetic aspects of enteric methane emission in livestock ruminants. Italian Journal of Animal Science, 12(3), 450- 458.

Dayyani, N., Karkudi, K., \& Zakerian, A. (2013). Special rumen microbiology. Interna Journal of Advanced Biological and Biomedical Research, 1(11), 1397-

El-Zaiat, H. M., Araujo, R. C., Soltan, Y. A., Morsy, A. S., Louvandini, H., Pires, A. V., Abdalla, A. L. (2014). Encapsulated nitrate and cashew nut shell liquid on blood rumen constituents, methane emission, and growth performance of lambs. Journal tional $\ldots \quad \&$ Animal Science, 92(5), 2214-2224.

Gebeyehu, A., \& Mekasha, Y. (2013). Defaunation : effects on feed intake, digestion, rumen metabolism and weight gain. J. Anim. Sci, 84(7), 1896-1906. https://doi.org/10.2527/jas.2005652

Glunk, E., March, K., Dave, W., \& Clain, J. (2015). Nitrate Toxicity of Montana Forages. Bozeman : Montana State University Extension.

Hapsari, Novia S., Dian W., Anis M. (2018). Fermentasi Pakan dengan Imbuhan Ekstrak Daun Babadotan (Ageratum conyzodies) dan Jahe (Zingiber Officinale) pada Sapi Perah Secara In Vitro. Jurnal agripet, 18(1), 1-9

Herliatika, A \& Widyawati, Y. (2021). Mitigation of Enteric Methane Emission through Feed Modification and Rumen Manipulation. WARTAZOA. 31(1), 1-12. DOI: http://dx.doi.org/10.14334/wartazoa.v31i1.2706

Holmes, D. E., Giloteaux, L., Orellana, R., Williams, K. H., Robbins, M. J., \& Lovley, $\quad$ D. R. (2014). Methane production from protozoan endosymbionts following stimulation of microbial metabolism within subsurface sediments. Frontiers in Microbiology, 6(5), 1-9. https://doi.org/10.3389/fmicb.2014.00366

Hristov, A. N., Oh, J., Firkins, J., Dijkstra, J., Kebreab, E., Waghorn, G., Makkar, H. P. S., Adesogan, A. T., Yang, W., Lee, C., Gerber, P. J., Henderson, B. and Tricarico, J. M. 2013. Special topics _ Mitigation of methane and nitrous oxide emissions from animal operations: I. A review of enteric methane mitigation options. J. Anim. Sci. 91, 5045-5069.

Hulshof, R. B. A., Berndt, A., Gerrits, W. J. J., Dijkstra, J., Van Zijderveld, S. M., Newbold, J. R., \& Perdok, H. B. (2012). Dietary nitrate supplementation reduces methane emission in beef cattle fed sugarcane-based diets. Journal of animal science, 90(7), 2317-2323.

Jayanegara, Anuraga., M Ridla., Erika B., \& Nahrowi. (2019). Komponen antinutrisi pada pakan. IPB press. Bogor

Jönck, F., Gava, A., Traverso, S. D., Lucioli, J., Furlan, F.H., \& Gueller, E. (2017). Spontaneous and experimental poisoning by nitrate/nitrite in cattle fed Avena sativa (oat) and/or Lolium spp. (ryegrass). Pesquisa Veterinária Brasileira, Rio de Janeiro, 33(9), 1062-1070, doi: 10.1590/S0100-736X2013000900003.

Lamid, M., Puspaningsih, N.N.T., dan Mangkoedihardjo, S. 2013. Addition of lignocellulolytic enzymes into rice straw improves in vitro rumen fermentation products.

Biol Sci, 3 (9), 166-171. 
Rohma et al.

ANIMPRO: Conference of Applied Animal Science Proceeding Series

Lee, C., Araujo, R. A., Koenig, K. M. and Beauchemin, K. A. (2014). Effects of encapsulated nitrate on toxicity, feed intake and feed consumption rates in beef cattle. J Anim Sci, 93 (10), 4956-66. doi: 10.2527/jas.2015-9435.

Lee, C., Araujo, R. A., Koenig, K. M. and Beauchemin, K. A. 2015. Effects of encapsulated nitrate on enteric methane production and nitrogen and energy utilization in beef heifers. J. Anim. Sci, 93(5), 2405-18. doi: 10.2527/jas.2014-8851

Leng, R. A., Preston, T. R., \& Inthapanya, S. (2012). Biochar reduces enteric methane and improves growth and feed conversion in local "Yellow" cattle fed cassava root chips and fresh cassava foliage. Livestock Research for Rural Develop ment, 24(11).

Li, L., Davis, J., Nolan, J., \& Hegarty, R. (2012). An initial investigation on rumen fermentation pattern and methane emission of sheep offered diets containing urea or nitrate as the nitrogen source. Animal Production Science, 52(7), 653-658.

Mamvura C, Cho S, Mbiriri D, Lee H, Choi N.(2014). Effect of Encapsulating Nitrate in Sesame Gum on In vitro Rumen Fermentation Parameters Anim Biosci. 27(11), 15771583. https://doi.org/10.5713/ajas.2014.14280

Mosoni, P., Martin, C., Forano, E., \& Morgavi, D. P. (2011). Long-term defaunation increases the abundance of cellulolytic ruminococci and methanogens but does not affect the bacterial and methanogen diversity in the rumen of sheep1. Journal of Animal Science, 89(3), 783-791. https://doi.org/10.2527/jas.2010-2947

Mustofa, Arif. (2015). Kandungan Nitrat dan Pospat Sebagai Faktor Tingkat Kesuburan Perairan Pantai. Jurnal DISPROTEK, 6(1), 13-19.

Norberg, S and Don, L. (2014). Nitrate poisoning in ruminants. Washington : Washingt on State Universsity Extension.

Pfister, J. A. (2019). Nitrate in toxication of ruminant livestock. In The ecology and economic impact of poisonous plants on livestock production (pp. 233-259). CRC Press.

Putri, W. A. E., Purwiyanto, A. I. S., Agustriani, F., \& Suteja, Y. (2019). Kondisi nitrat, nitrit, amonia, fosfat dan BOD di muara Sungai Banyuasin, Sumatera Se lat an. Jurnal IImu dan Teknologi Kelautan Tropis, 11(1), 65-74. doi:10.29244/jitkt.v11i1.18861.

Van Zijderveld, S. M. (2011). Dietary strategies to reduce methane emissions from ru minants. Wageningen University, Wageningen.

van Zijderveld, S. M., Gerrits, W. J., Dijkstra, J., Newbold, J. R., Hulshof, R. B., \& Perdok, H. B. (2011). Persistency of methane mitigation by dietary nitrate supplementation in dairy cows. Journal of dairy science, 94(8), 4028-4038. https://doi.org/10.3168/jds.2011-4236

van Zijderveld, S. M., Gerrits, W. J., Apajalahti, J. A., Newbold, J. R., Dijkstra, J., Leng, R. A., \& Perdok, H. B. (2010). Nitrate and sulfate: Effective alternative hydrogen sinks for mitigation of ruminal methane production in sheep. Journal of dairy science, 93(12), 58565866. https://doi.org/10.3168/jds.2010-3281

Wang, Y., Zhou, W., Jia, R., Yu, Y., \& Zhang, B. (2020). Unveiling the activity origin of a copper-based electrocatalyst for selective nitrate reduction to ammo nia. Angewandte Chemie, 132(13), 5388-5392.

Widiawati Y, Herliatika A, Zuratih, saptati RA. (2019). Emisi dari subsektor peter nakan. Dalam: Metode penilaian adaptasi dan inventarisasi gas rumah kaca sektor pertanian. Agus F, penyunting. Jakarta (Indonesia): IAARD Press.

Yanuartono, Alfarisa, N., Soedarmanto. I., Hary. P. (2019). Peran protozoa pada pencernaan ruminansia dan dampak terhadap lingkungan. Journal of Tropical Ani mal Production, 20 (1), 16-28. DOI: 10.21776/ub.jtapro.2019.020.01.3

Zhou, Z., Yu, Z., \& Meng, Q. (2012). Effects of nitrate on methane production, fermentation, and microbial populations in in vitro ruminal cultures. Bioresource tech nology, 103(1), 173179. https://doi.org/10.1016/j.biortech.2011.10.013 